\title{
Morphological alterations in the ovaries of Amblyomma cajennense semi-engorged ticks exposed to ethanolic extract of Acmella oleracea
}

\author{
Luís Adriano Anholeto ${ }^{1}$ () | Patrícia Rosa de Oliveira ${ }^{1}$ () | \\ Rodney Alexandre Ferreira Rodrigues ${ }^{2}$ (1) | Lais Thiemi Yamane ${ }^{2}$ | \\ Karina Neoob de Carvalho Castro ${ }^{3}$ | Maria Izabel Camargo-Mathias ${ }^{1}$ ()
}

${ }^{1}$ Department of Biology, Institute of Biosciences, São Paulo State University UNESP, Rio Claro, SP, Brazil

${ }^{2}$ Chemical, Biological and Agricultural Research Center (CPQBA), Natural Products Chemistry Division, University of Campinas, Campinas, SP, Brazil

${ }^{3}$ Embrapa Meio-Norte, Parnaíba, PI, Brazil

Correspondence

Email: micm@rc.unesp.br

Funding information

Coordenação de Aperfeiçoamento de Pessoal de Nível Superior; Fundação de Amparo à

Pesquisa do Estado de São Paulo, Grant/Award Number: 2015/01496-5

\begin{abstract}
The present study analyzed the effects of different concentrations of Acmella oleracea crude ethanolic extract (EEAO) on the development of germ cells from semi-engorged Amblyomma cajennense females in order to evaluate the potential of this natural chemical as a strategy to control these important ectoparasites. A hundred semi-engorged females were divided into five groups (duplicates) (10 animals/group): Control 1 (distilled water); Control 2 (solvent ethanol $50 \%$ and DMSO 1\%); and Treatment I to III (3.1, 6.2, and $12.5 \mathrm{mg} / \mathrm{mL}$ of EEAO, respectively). For the exposure of the ticks to the extract was used the Adult Immersion Test. After the exposition, the ovaries were removed and submitted to histological analysis using Harris hematoxylin and aqueous eosin. The histochemical tests were performed using PAS and Bromophenol blue staining techniques, for the detection of total polysaccharides and total protein, respectively. The extract caused significant alterations in the oocytes, including changes in the shape of the cells, disorganization, and cytoplasmic vacuolation, decrease in the number of yolk granules and germ vesicle fragmentation. These alterations were more intense in the oocytes in initial developmental stages (I and II). The results obtained in this study confirm the cytotoxic potential of the ethanolic extract of $A$. oleracea on the germ cells of $A$. cajennense females, opening up the possibility to use this extract as an alternative to control these ectoparasites.
\end{abstract}

\section{KEYWORDS}

control, jambu, morphology, oocytes, ticks

\section{1 | INTRODUCTION}

The medical and veterinary importance of ticks of the Amblyomma cajennense (Fabricius, 1787) species complex is widely acknowledged, as they have different hosts, including the human being (Sonenshine \& Roe, 2014). Additionally, these ectoparasites are potential vectors of Rickettsia rickettsii, the causative agent of Rocky Mountain Spotted Fever and Brazilian Spotted Fever (Labruna, 2009; Martins et al., 2016; Soares et al., 2015; Tarragona et al., 2015). This species group is spread throughout the American continent (Beati et al., 2013; Estrada-Peña \& De La Fuente, 2014), where two species are reported in Brazil: A. cajennense sensu stricto in the Amazon Basin

The authors declare that there are no conflicts of interest. (northern Brazil), and Amblyomma sculptum in the remaining regions of the country, except for the extreme south where this species group is absent (Martins et al., 2016).

The female reproductive system of Amblyomma cajennense ticks was described by Denardi et al. (2004). According to the authors, the ovary of these ticks is panoistic and comprised of many oocytes (germ cells) in developmental stages classified from I to V. These oocytes are attached to the ovary through a cellular pedicel (Denardi et al., 2004; Oliveira, Bechara, Denardi, Nunes, \& Camargo-Mathias, 2005; Saito et al., 2005).

The widely used method to control ticks is the use of synthetic chemical acaricides (Nolan, 1985; Oliveira et al., 2015; Oliveira, Bechara, Denardi, Pizano, \& Camargo-Mathias, 2011; Pruett, 1999). However, the indiscriminate use of such products can induce the 
selection of resistant individuals and to the accumulation of chemical residues in the environment, contaminating the soil and water streams, and consequently affecting other animals, including human beings (Anholeto et al., 2017; Oliveira, Bechara, \& Camargo-Mathias, 2008).

In this sense, new ticks control strategies have been promising as the use of vaccines and chemical acaricides of natural origin, with active ingredients based on plant extracts (Agnolin et al., 2010; Anholeto et al., 2017; Castro et al., 2014).

The use of natural substances represents an alternative to control ectoparasites (Borges, Sousa, \& Barbosa, 2011). In this scenario, plants of the Meliaceae family, including the members of the genus Melia (Oelrichs, Hill, Vallely, MacLeod, \& Molinski, 1983), Trichilia, Toona, Aglaia and Azadirachta (Martinez, 2002) and the Asteraceae family, such as the species Acmella oleracea have been widely recognized as effective strategies to control pests (Anholeto et al., 2017; Castro et al., 2014; Oliveira, Castro, Anholeto, Camargo-Mathias, \& Camargo-Mathias, 2016).

Acmella oleracea (L.) R.K. Jansen (Asteraceae), is a plant found in tropical regions close to the Equator in Africa, Asia, and South America. In Brazil, it is popularly known as Jambu among other names, and it is used as a condiment, ingredient in popular medicine and its pharmacological activities have been object to several studies (Barbosa, Carvalho, Smith, \& Sabaa-Srur, 2016; Cheng et al., 2015; Favoreto \& Gilbert, 2010; Nomura et al., 2013). Recent studies have shown that the extract of the flowers, leaves and stem of A. oleracea have fungistatic, fungicide, and insecticide properties (Barbosa et al., 2016; Dubey, Maity, Singh, Saraf, \& Saha, 2013; Fabry, Okemo, \& Ansorg, 1996; Favoreto \& Gilbert, 2010; Nigrinis, Caro, \& Olarte, 1986; Ramsewak, 1999; Torres \& Chávez, 2001).

Castro et al. (2014) and Oliveira et al. (2016) demonstrated that the $n$-hexane extracts of $A$. oleracea would have acaricide action, causing death in larvae and engorged females of the tick species Rhipicephalus microplus, in addition to interfering in the dynamics of the female reproductive system, significantly affecting oviposition and hatchability.

Thus, the objective of the present study was to investigate the effects of different concentrations of $A$. oleracea extract on germinative cells of semi-engorged $A$. cajennense ticks through morphological, histological and histochemical techniques. The results provide relevant information for the development of sustainable strategies and the improvement of current methods to control these ticks, minimizing environmental contamination, tick-resistance development and risks to nontarget organisms as well.

\section{MATERIALS AND METHODS}

\section{1 | Chemical substance}

\subsubsection{Acmella oleracea}

The plants were cultivated in the experimental field of the CPQBA/UNICAMP, Paulinia, SP, Brazil, geographic coordinates $22^{\circ} 47^{\prime} 52^{\prime \prime} \mathrm{S}, 47^{\circ} 6^{\prime} 49^{\prime \prime} \mathrm{W}$. The seeds were provided by the company Centroflora (Botucatu, SP, Brazil) and the aerial parts (flowers, leaves, and stem) were collected in April 2015. The plant was identified by Dr. John F. Pruski of Missouri Botanical Garden (USA), and a voucher specimen was deposited in CPQBA/UNICAMP Herbarium, Campinas, SP, Brazil, number 181,452 . This project was authorized by the Council of the Genetic Heritage Management, under protocol number 010577/2014-9.

\subsubsection{Preparing the crude ethanolic extract of Acmella oleracea}

The crude ethanolic extract of the aerial parts (flowers, leaves, and stem) of A. oleracea (EEAO) was prepared according to Anholeto et al. (2017b).

\subsection{Hosts}

Grupo Genético Botucatu rabbits, weighing between 3 and $3.5 \mathrm{~kg}$, were used as hosts. Rabbits were obtained from the Animal Facility of UNESP - Botucatu Campus/São Paulo - Brazil and housed in the Animal Facility of UNESP - Rio Claro Campus/São Paulo - Brazil. The animals had not been exposed previously to ticks or acaricides and were kept under controlled conditions. During the entire experiment, the rabbits were maintained in individual cages, receiving water and commercial food ad libitum.

This study was approved by the Ethics Committee for Animal Experimentation of UNESP/SP/Brazil, protocol n ${ }^{\circ} 11 / 2015$.

\section{3 | Amblyomma cajennense ticks}

The Amblyomma cajennense semi-engorged females weighing $27 \mathrm{mg}$ on average were used throughout the experiment. The ticks were provided by the Animal Facility of the Department of Biology - UNESP, Rio Claro Campus/São Paulo, Brazil, where the colony is maintained under controlled conditions $\left(28^{\circ} \mathrm{C}, 85 \%\right.$ humidity, and 12 -hr photoperiod) in a Biological Oxygen Demand incubator. Unfed A. cajennense couples were fed for 10 days (semi-engorged stage) on two naive Grupo Genético Botucatu rabbits (50 couples of ticks/rabbit) (duplicates) following Bechara et al. (1995). Females studied here were collected in the feeding stage of semi-engorgement, with the intention of approaching the conditions observed in the field. In this stage of feeding, the females ticks remain attached to the host's skin to complete the blood meal, a process that leads to the appearance of skin lesions, as well as an open door for the transmission of pathogens to hosts.

\section{4 | Experimental design}

Adult ticks with homogeneous weights $(p>0.05)$, were divided into five groups (10 ticks each):

\begin{tabular}{ll}
\hline Group & $\begin{array}{l}\text { Exposition } \\
\text { Control group I }\end{array}$ \\
$\begin{array}{l}\text { Distilled water } \\
\text { Control group II } \\
\text { dimethyl sulfoxide (DMSO) at } 1 \%\end{array}$ \\
\hline Treatment I & $3.1 \mathrm{mg} / \mathrm{mL}$ of EEAO \\
\hline Treatment II & $6.2 \mathrm{mg} / \mathrm{mL}$ of EEAO \\
\hline Treatment III & $12.5 \mathrm{mg} / \mathrm{mL}$ of EEAO \\
\hline
\end{tabular}

The sublethal concentrations used in the treatment were based on previous studies by Anholeto et al. (2017). 
The Adult Immersion Test (Drummond et al., 1973) was used for the tick exposure to the crude ethanolic extract of A. oleracea.

\section{5 | Morphophysiological evaluation}

All semi-engorged females maintained in the refrigerator for thermal shock anesthesia were dissected using stereomicroscope in a phosphate buffered saline-PBS solution ( $\mathrm{NaCl} 7.5 \mathrm{~g} / \mathrm{L}, \mathrm{Na}_{2} \mathrm{HPO}_{4} 2.38 \mathrm{~g} / \mathrm{L}$, and $\mathrm{KH}_{2} \mathrm{PO}_{4} 2.72 \mathrm{~g} / \mathrm{L}$ ).

\subsection{1 | Histology}

a. Harris hematoxylin and aqueous eosin technique (Junqueira and Junqueira, 1983).

The ovaries were fixed for $24 \mathrm{hr}$ in $4 \%$ paraformaldehyde, dehydrated in ethanol, embedded in Leica resin for $24 \mathrm{hr}$ at $4^{\circ} \mathrm{C}$ and transferred to plastic molds previously filled with polymerized Leica resin. After resin polymerization, all the blocks were sectioned at $3 \mu \mathrm{m}$ thickness slices using a Leica RM 2265 microtome (Leica ${ }^{\circledR}$ ) and stained with hematoxylin and eosin, following routine histological procedures. The permanent slides were analyzed and documented using brightfield microscope Leica DM750 (Leica ${ }^{\circledR}$ ).

\section{b. Histochemistry}

To detect changes such as presence or absence, frequency, and distribution of proteins and polysaccharides in the semi-engorged females of control and extract-treated groups, histological sections were prepared for the histochemical techniques listed below.

PAS technique for Polysaccharide Detection (Junqueira and Junqueira 1983):

The ovaries of semi-engorged females were fixed with aqueous Bouin. Slides with sections were immersed for $10 \mathrm{~min}$ in $0.4 \%$ periodic acid, washed with distilled water, and stained with Schiff's reagent for $1 \mathrm{hr}$ in the dark. The material was then washed thrice with sulfur water for $3 \mathrm{~min}$ each and rinsed with tap water for $30 \mathrm{~min}$. Then, the material was stained with hematoxylin for 5 min. After drying, slides were clarified with xylol and mounted in Canada balsam.

Bromophenol Blue Staining for Protein Detection (Pearse 1985):

The ovaries of semi-engorged females were fixed with $4 \%$ paraformaldehyde. All slides were stained with bromophenol blue for $2 \mathrm{hr}$ at room temperature. Afterward, they were washed with $0.5 \%$ acetic acid for $5 \mathrm{~min}$ and tap water for $15 \mathrm{~min}$; slides were quickly immersed in tertiary butyl alcohol, allowed to dry at room temperature, clarified, and mounted in Canada balsam.

\section{3 | RESULTS}

\section{1 | Histology}

\subsection{1 | Control Groups I and II.}

The results showed that the ovary of $A$. cajennense is a tubular horseshoe-shaped structure, limiting a lumen, where a considerable number of oocytes undergoing several stages of development (I to $\mathrm{V}$ ) are fixed through the pedicel cells (Figure 1a-e). In the control groups I and II, the oocytes I were small elliptical cells presenting a germ vesicle with an evident nucleolus in the central part of the cytoplasm (Figure 1a). The cytoplasm had a homogeneous aspect, with no granulations, and was limited by a thin plasma membrane, (Figure 1a). Oocytes II were larger than oocytes I, elliptical, and had a central germ vesicle (Figure 1b). The cytoplasm, limited by a thin plasma membrane, showed some thin and homogenous granulations (Figure 1b). Oocytes III showed rounded shape and intermediate size (Figure 1c). The germ vesicle was located in the oocyte pole, facing the pedicel (Figure 1c). The cytoplasm was filled with yolk granules of varied sizes, the smallest of which found in the central region and the largest in the periphery of the cells (Figure 1c). The plasma membrane was thick and it was possible to observe the chorion deposition (Figure 1c). The Oocytes IV were elliptical and larger than oocytes III, the cytoplasm was filled with large yolk grains homogeneously distributed (Figure 1d). At this stage, it was possible to observe the complete deposition of the chorion (Figure 1d). The germ vesicle was located at the oocyte pole facing the pedicel (Figure 1d). Oocytes $V$ were also observed, round, and larger than IV ones, with large yolk granules homogeneously distributed in the cytoplasm, which did not allow the germ vesicle to be observed. These oocytes were involved by the fully deposited chorion (Figure 1e).

\subsection{2 | Treatment I: Exposed to $3.1 \mathrm{mg} / \mathrm{mL}$ of EEAO.}

The oocytes belonging to this group showed morphological alterations throughout the ovary in comparison with control groups I and II, including changes in the original shape of all oocytes (I, II, III, and V), from elliptic or round-shaped to irregular (Figure 1f-j). Oocytes I, II, and III showed cytoplasmic disorganization (Figure 1f-h). Oocytes IV showed decreased number of yolk granules, mainly in the peripheral region (Figure $1 \mathrm{~h}$-j). Additionally, the germ vesicle showed fragmentation in oocytes IV (Figure 1i) and a thicker chorion was deposited in oocytes IV and V (Figure 1i, j). The chorion of oocytes $V$ was folded, which altered its original shape (Figure $1 \mathrm{j}$ ).

\subsection{3 | Treatment II: Exposed to $6.2 \mathrm{mg} / \mathrm{mL}$ of EEAO.}

The results showed the occurrence of more significant morphological alterations, mainly in the oocytes in initial stages of development (I and II) (Figure 1k, I). The cells lost their original shape, from round to irregular. Large cytoplasmic vacuoles of the oocytes I and II were observed (Figure 1k, I). The oocytes I displayed chromatin marginalization in the germ vesicle (Figure $1 \mathrm{k}$ ). In the oocytes $\mathrm{V}$, the chorion was less folded in comparison with the Treatment Group I (Figure 10).

\subsection{4 | Treatment III: Exposed to $12.5 \mathrm{mg} / \mathrm{mL}$ of EEAO.}

The females belonging to this group showed more intense morphological alterations (Figure 1p-t), such as a change in the shape of oocytes I (Figure 1p), cytoplasmic disorganization in oocytes I and II, and vacuolation in the oocytes II (Figure 1q). Yolk granules were smaller in oocytes III (Figure 1r) and oocytes IV when compared to the Control Groups I and II (Figure 1s). In the oocytes V, the yolk granules were ruptured, and their content was released in the cytoplasm (Figure 1t). 


$\begin{array}{cccc}\text { Control } & \text { Treatment I } & \text { Treatment II } & \text { Treatment III } \\ \text { I and II } & 3.1 \mathrm{mg} / \mathrm{mL} & 6.2 \mathrm{mg} / \mathrm{mL} & 12.5 \mathrm{mg} / \mathrm{mL}\end{array}$
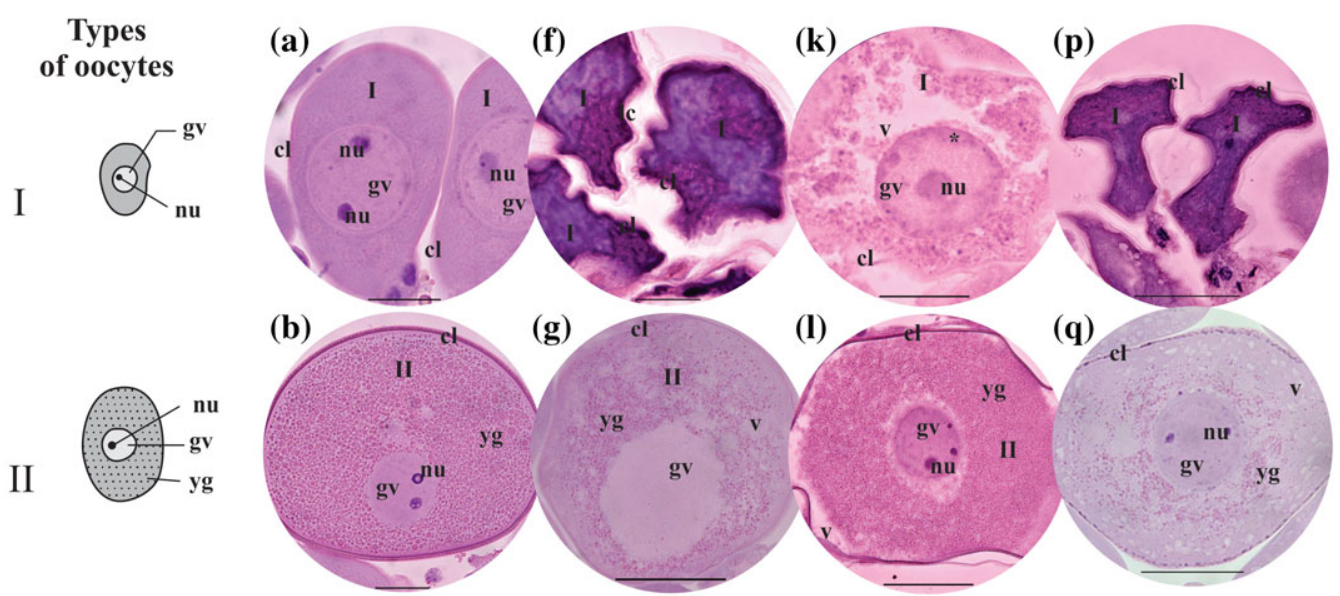

(q)

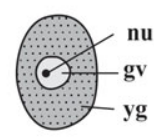

(c)
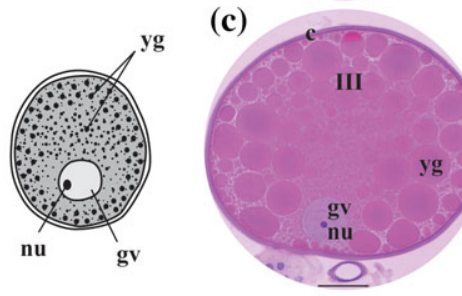

(h)
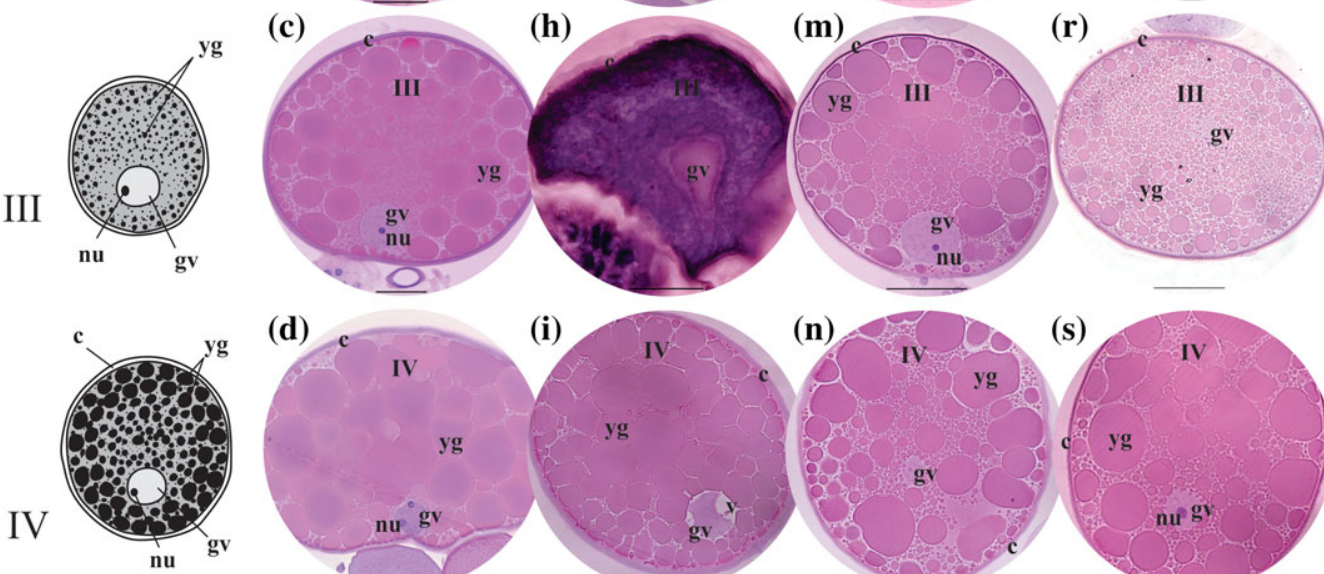

(d)

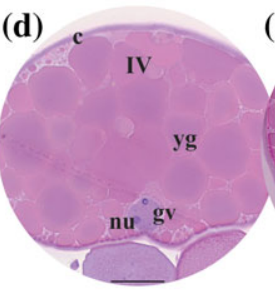

(i)
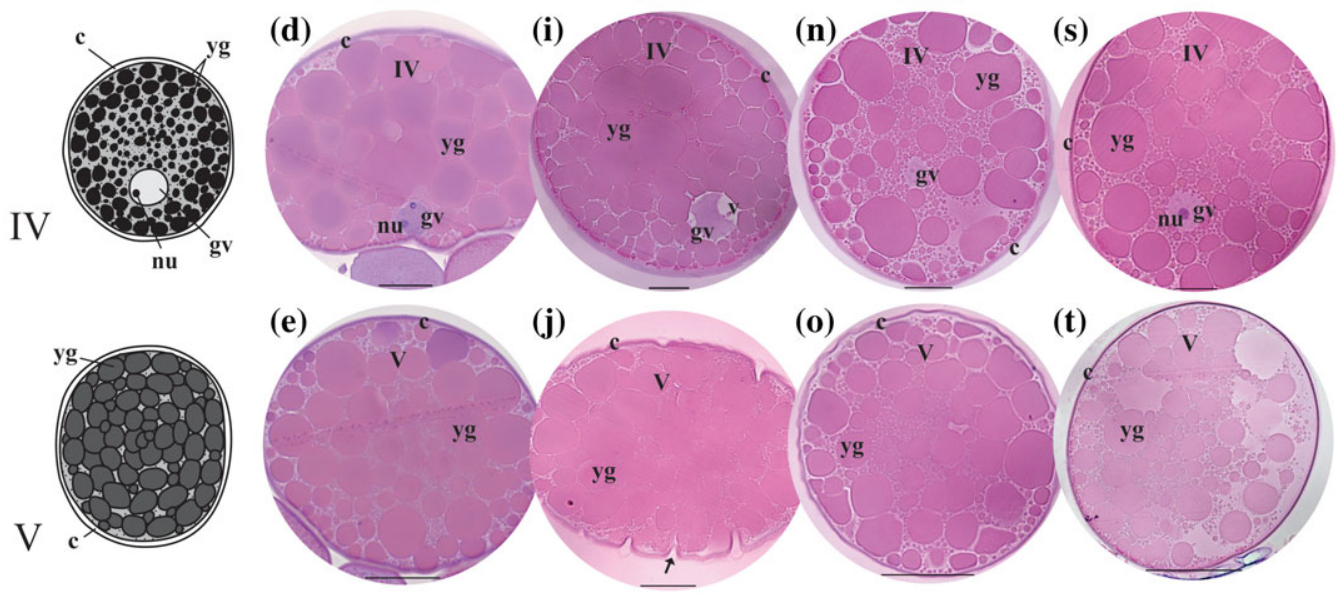

FIGURE 1 Schematic representation of the oocytes (adapted from Oliveira et al. 2005) and histological sections of the ovary from Amblyomma cajennense stained with hematoxylin and eosin (a-e) control groups I and II. ( $f-j$ ) Females exposed to $3.1 \mathrm{mg} / \mathrm{mL}$ of the EEAO. (k-o) Females exposed to $6.2 \mathrm{mg} / \mathrm{mL}$ of the EEAO. (p-t) Females exposed to $12.5 \mathrm{mg} / \mathrm{mL}$ of the EEAO. I = oocyte I; II = oocyte II; III = oocyte III; IV = oocyte $\mathrm{IV} ; \mathrm{V}=$ oocyte $\mathrm{V} ; \mathrm{c}=$ chorion; $\mathrm{yg}=$ yolk granules; $\mathrm{cl}=$ cell limit; $\mathrm{n}=$ nucleus; $\mathrm{nu}=$ nucleolus; $\mathrm{v}=$ vacuole; gv = germ vesicle; * = chromatin marginalization; arrow = chorion folds. Bars $=a-d ; f-i ; k-n ; p-s=50 \mu \mathrm{m} ; \mathrm{e} ; \mathrm{j} ; \mathrm{o} ; \mathrm{t}=100 \mu \mathrm{m}$ [Color figure can be viewed at wileyonlinelibrary.com]

\section{2 | Histochemistry}

a. PAS reaction for the detection of neutral polysaccharides (Junqueira and Junqueira, 1983)

PAS histochemical test results are summarized in Table 1.

\section{Control Groups I and II.}

The use of PAS (periodic acid - Schiff) histochemical test revealed the presence of polysaccharides in the oocytes of the A. cajennense semiengorged females. Oocytes I presented rare positive granulation and weakly positive cytoplasm to PAS (Figure 2a). However, oocytes II showed weakly positive cytoplasm with strongly positive fine granulation to PAS (Figure $2 b$ ). The germ vesicle of these oocytes (I and II) did not react to the test, whereas the plasma membrane (oocyte I) showed moderate positivity (Figure 2a,b). The cytoplasm of oocytes III was filled with yolk granules of varied sizes, the smaller ones located in the central region and strongly positive, while the larger ones, moderately positive for PAS, were found in the periphery of the cells, and (Figure $2 \mathrm{c}$ ). The germ vesicle reacted negatively, and the chorion reacted moderately (Figure 2c).

In the oocytes IV, the cytoplasm showed large moderately positive granules and smaller strongly positive ones. The germ vesicle was negative to the technique and the chorion was moderately positive (Figure $2 \mathrm{~d}$ ). The oocytes $\mathrm{V}$ presented large yolk granules homogenously distributed in the cytoplasm and weakly positive for PAS (Figure 2e). These oocytes showed a moderately positive chorion; however, the germ vesicle was not observed (Figure 2e). 
TABLE 1 Results of the PAS (periodic acid Schiff) histochemical test applied in the female reproductive system of A. cajennense s.s. for the detection of neutral polysaccharides

\begin{tabular}{|c|c|c|c|c|c|c|c|c|c|}
\hline $\begin{array}{l}\text { Types of } \\
\text { oocýtes }\end{array}$ & $\begin{array}{l}\text { Oocyte } \\
\text { region }\end{array}$ & $\begin{array}{l}\text { Control } \\
\text { I and II }\end{array}$ & Figure & $\begin{array}{l}\text { Treatment I } \\
\text { (3.1 } \mathrm{mg} / \mathrm{mL})\end{array}$ & Figure & $\begin{array}{l}\text { Treatment II } \\
(6.2 \mathrm{mg} / \mathrm{mL})\end{array}$ & Figure & $\begin{array}{l}\text { Treatment III } \\
\text { (12.5 mg/mL) }\end{array}$ & Figure \\
\hline \multirow[t]{5}{*}{ I } & Cell limit & ++ & $2 a$ & ++ & $2 f$ & ++ & $2 \mathrm{k}$ & ++ & $2 p$ \\
\hline & Cytoplasm & + & & + & & - & & - & \\
\hline & $\begin{array}{l}\text { Yolk } \\
\text { granules }\end{array}$ & $\varnothing$ & & $\varnothing$ & & $\varnothing$ & & $\varnothing$ & \\
\hline & $\begin{array}{l}\text { Germ } \\
\quad \text { vesicle }\end{array}$ & - & & - & & - & & - & \\
\hline & Nucleolus & ++ & & ++ & & ++ & & ++ & \\
\hline \multirow[t]{5}{*}{ II } & Cell limit & ++ & $2 b$ & ++ & $2 g$ & ++ & 21 & ++ & $2 q$ \\
\hline & Cytoplasm & + & & +++ & & +++ & & +++ & \\
\hline & $\begin{array}{l}\text { Yolk } \\
\text { granules }\end{array}$ & ++ & & ++ & & +++ & & +++ & \\
\hline & $\begin{array}{l}\text { Germ } \\
\quad \text { vesicle }\end{array}$ & - & & - & & - & & - & \\
\hline & Nucleolus & $\varnothing$ & & $\varnothing$ & & ++ & & ++ & \\
\hline \multirow[t]{5}{*}{ III } & Chorion & ++ & $2 c$ & ++ & $2 \mathrm{~h}$ & +++ & $2 m$ & ++ & $2 r$ \\
\hline & Cytoplasm & +++ & & +++ & & +++ & & +++ & \\
\hline & $\begin{array}{l}\text { Yolk } \\
\text { granules }\end{array}$ & +++ & & +++ & & +++ & & +++ & \\
\hline & $\begin{array}{l}\text { Germ } \\
\quad \text { vesicle }\end{array}$ & - & & - & & - & & - & \\
\hline & Nucleolus & $\varnothing$ & & ++ & & ++ & & ++ & \\
\hline \multirow[t]{5}{*}{ IV } & Chorion & ++ & $2 d$ & ++ & $2 \mathrm{i}$ & +++ & $2 n$ & ++ & $2 s$ \\
\hline & Cytoplasm & +++ & & +++ & & +++ & & +++ & \\
\hline & $\begin{array}{l}\text { Yolk } \\
\quad \text { granules }\end{array}$ & +++ & & +++ & & +++ & & +++ & \\
\hline & $\begin{array}{l}\text { Germ } \\
\text { vesicle }\end{array}$ & - & & - & & - & & - & \\
\hline & Nucleolus & ++ & & $\varnothing$ & & $\varnothing$ & & $\varnothing$ & \\
\hline \multirow[t]{5}{*}{ V } & Chorion & +++ & $2 e$ & +++ & $2 j$ & +++ & 20 & +++ & $2 t$ \\
\hline & Cytoplasm & +++ & & +++ & & +++ & & +++ & \\
\hline & $\begin{array}{l}\text { Yolk } \\
\text { granules }\end{array}$ & ++ & & ++ & & +++ & & +++ & \\
\hline & $\begin{array}{l}\text { Germ } \\
\quad \text { vesicle }\end{array}$ & $\varnothing$ & & $\varnothing$ & & $\varnothing$ & & $\varnothing$ & \\
\hline & Nucleolus & $\varnothing$ & & $\varnothing$ & & $\varnothing$ & & $\varnothing$ & \\
\hline
\end{tabular}

+ weakly positive; ++ moderately positive; +++ strongly positive; - negative; $\varnothing$ region not observed.

\section{Treatment l: Exposed to $3.1 \mathrm{mg} / \mathrm{mL}$ of EEAO.}

When submitted to the PAS reaction, the $A$. cajennense semiengorged females exposed to the A. oleracea ethanolic extract at the concentration of $3.1 \mathrm{mg} / \mathrm{mL}$ showed polysaccharides in the oocytes, and significant morphological alterations when compared to the control groups I and II. Oocytes I were unaffected by the treatment (Figure 2f). On the other hand, the oocytes II presented fine strongly positive granulation in the central region, in addition to a thickened and moderately positive plasma membrane (Figure $2 \mathrm{~g}$ ). In oocytes IV, the cytoplasm presented large and moderately positive bead granules of and smaller and strongly positive granules (Figure 2i). The oocytes III (Figure $2 \mathrm{~h}$ ) and $\mathrm{V}$ presented the same characteristics described in the control group (Figure 2j).

\section{Treatment II: Exposed to $6.2 \mathrm{mg} / \mathrm{mL}$ of EEAO.}

In the oocytes I, the cytoplasm did not react to PAS technique (Figure 2k). In oocytes II, there was a loss of yolk granules, mainly in the peripheral region of the cytoplasm and around the germ vesicle, which was strongly positive to the technique. The plasma membrane was irregular and moderately positive (Figure 2I). The oocytes III presented larger yolk granules in the periphery and smaller ones in the central region of the cytoplasm, both of strong positivity (Figure $2 \mathrm{~m}$ ). The oocytes IV presented strongly positive yolk granules, fewer in comparison with the control group (Figure $2 n$ ). The oocytes $V$ showed strongly positive yolk granules, fewer in comparison with the control group (Figure 2o).

\section{Treatment III: Exposed to $12.5 \mathrm{mg} / \mathrm{mL}$ of EEAO.}

The female reproductive system of $A$. cajennense exposed to A. oleracea ethanolic extract at the concentration of $12.5 \mathrm{mg} / \mathrm{mL}$ showed polysaccharides in the oocytes when submitted to PAS technique. In the oocytes I, the germ vesicle and the cytoplasm did not react to PAS (Figure 2p). In the oocytes II, loss of yolk granules was observed, mainly in the peripheral region of the oocyte cytoplasm, which in turn was strongly positive for PAS. The plasma membrane was irregular and moderately positive (Figure 2q). The oocytes III 


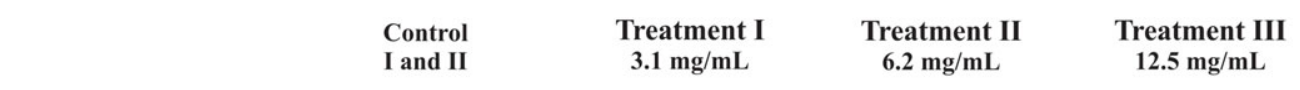

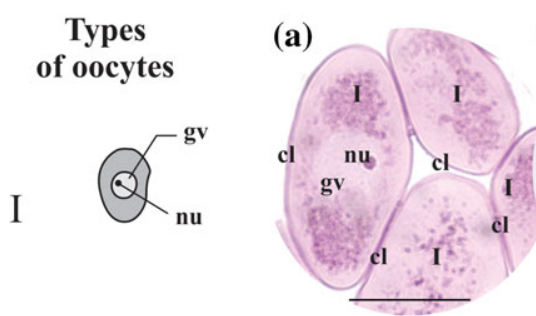

(b)
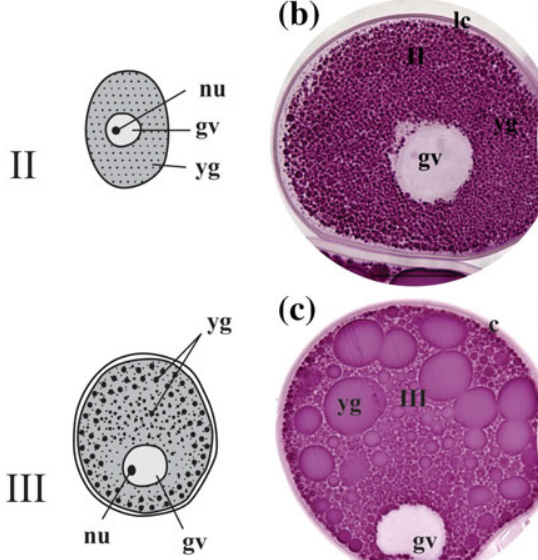

(c)

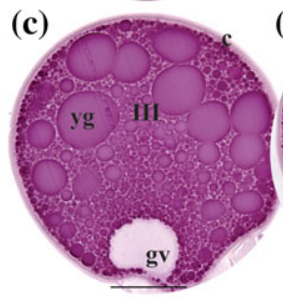

(d)
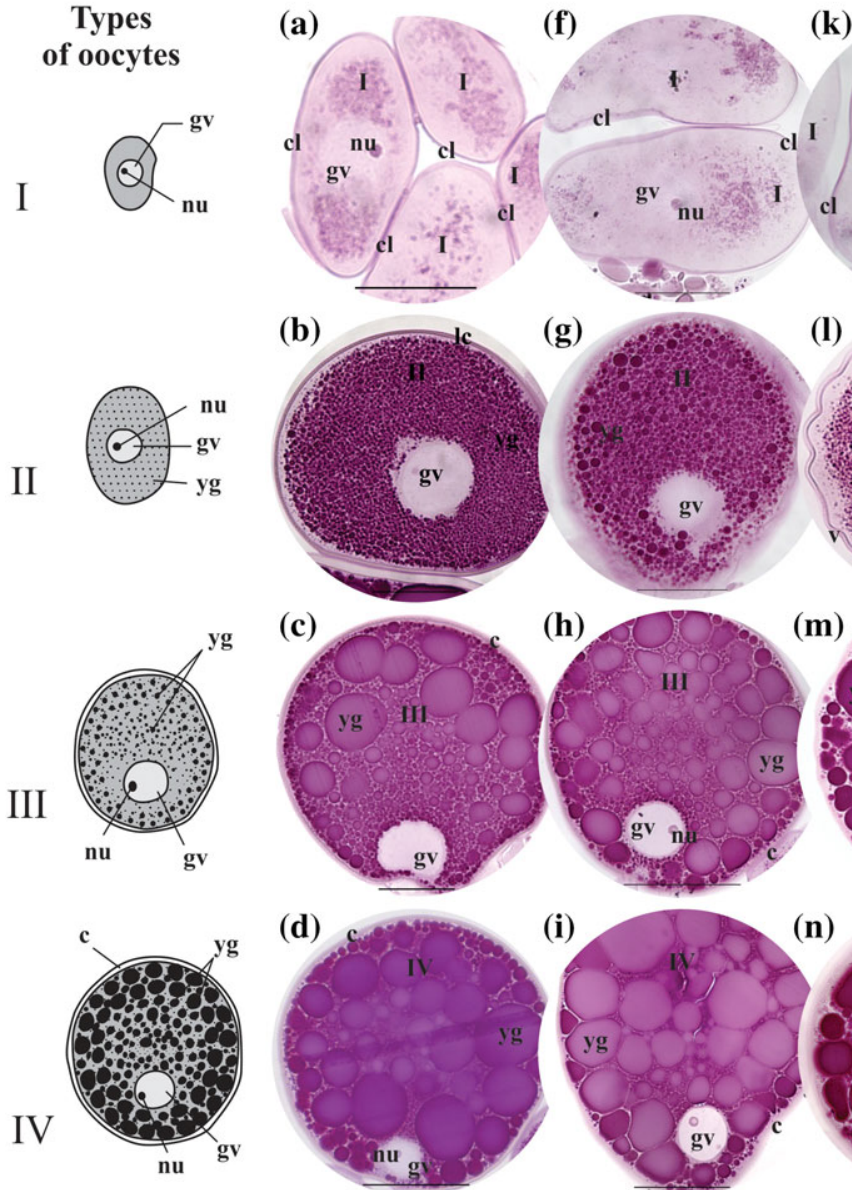

(k)

(g)

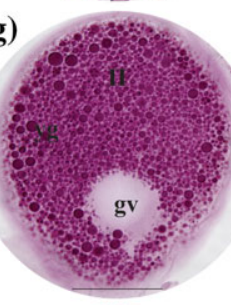

(I)

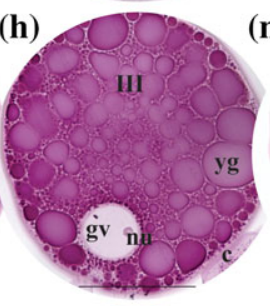

$(\mathbf{m}) \mathrm{c}$
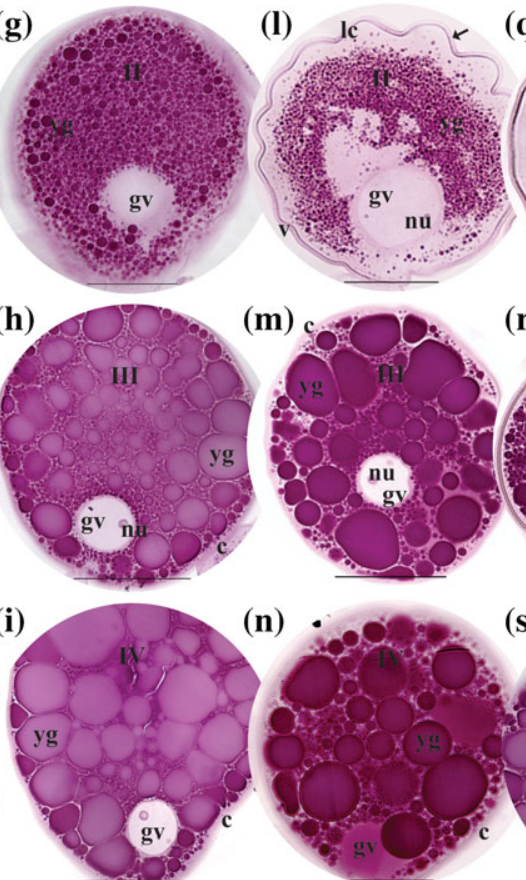

(n)
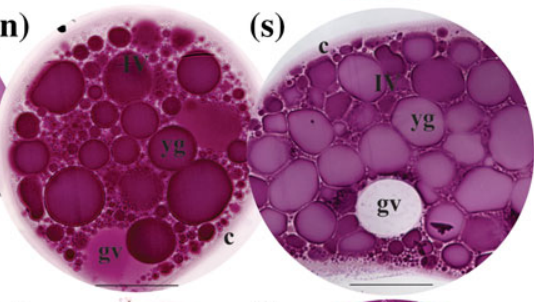

(e)

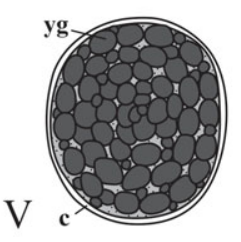

(o)

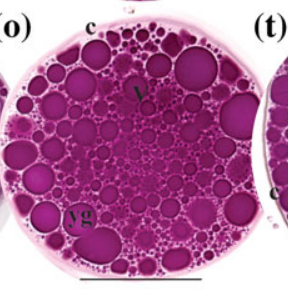

(t)

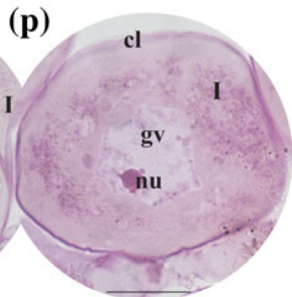

(q)

(r)
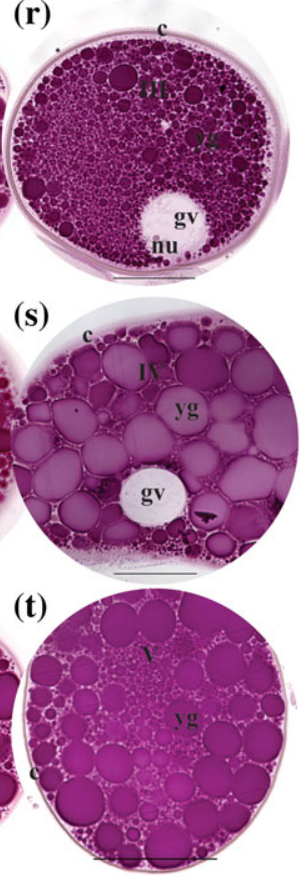

FIGURE 2 Schematic representation of the oocytes (adapted from Oliveira et al. 2005) and histological sections of the ovary from Amblyomma cajennense subjected to PAS reaction (periodic acid Schiff). (a-e) Control groups I and II. (f-j) Females exposed to $3.1 \mathrm{mg} / \mathrm{mL}$ of the EEAO. (k-o) Females exposed to $6.2 \mathrm{mg} / \mathrm{mL}$ do EEAO. (p-t) Females exposed to $12.5 \mathrm{mg} / \mathrm{mL}$ of the EEAO. I = oocyte I; II = oocyte II; III = oocyte III; $\mathrm{IV}=$ oocyte IV; $\mathrm{V}=$ oocyte $\mathrm{V} ; \mathrm{c}=$ chorion; $\mathrm{yg}=$ yolk granules; $\mathrm{cl}=$ cell limit; $\mathrm{n}$ = nucleus; $\mathrm{nu}=$ nucleolus; gv = germ vesicle. Bars = $\mathrm{a}-\mathrm{d} ; \mathrm{f}-\mathrm{i} ; \mathrm{k}-\mathrm{n}$; $\mathrm{p}-\mathrm{s}=50 \mu \mathrm{m} ; \mathrm{e} ; \mathrm{j} ; \mathrm{o} ; \mathrm{t}=100 \mu \mathrm{m}$ [Color figure can be viewed at wileyonlinelibrary.com]

presented strongly positive yolk granules, smaller than those of the control group (Figure $2 r$ ). The oocytes IV showed the same characteristics described in the control groups (Figure 2s). The oocytes $\mathrm{V}$ showed strongly positive yolk granules, fewer in comparison with the control group (Figure 2t).

\section{b. Bromophenol blue reaction for the detection of total protein (Pearse, 1985)}

Bromophenol blue histochemical test results are summarized in Table 2.

\section{Control Groups I and II.}

The bromophenol blue reaction revealed a large amount of protein in the oocytes of the $A$. cajennense semi-engorged female ticks, characterized by an intense positive reaction in the yolk granules distributed throughout the cytoplasm. In the oocytes I, the cytoplasm and the germ vesicle were weakly positive to bromophenol blue, whereas the nucleolus was strongly positive (Figure 3a). The plasma membrane was weakly positive (Figure 3a). Oocytes II showed strongly positive yolk granules homogeneously distributed throughout the cytoplasm (Figure $3 b$ ). The germ vesicle was weakly positive to bromophenol blue, and the plasma membrane was moderately positive (Figure 3b). The oocytes III presented large and weakly positive yolk granules, located mainly in the central region of the cytoplasm, whereas granules of smaller size and high positivity were found in the peripheral region of the cytoplasm (Figure 3c). The germ vesicle, located at the pole facing the oocyte pedicel, was weakly reactive to the bromophenol blue, whereas the chorion showed moderate 
TABLE 2 Results of the bromophenol blue histochemical test applied in the female reproductive system of $A$. cajennense s.s. for the detection of total protein

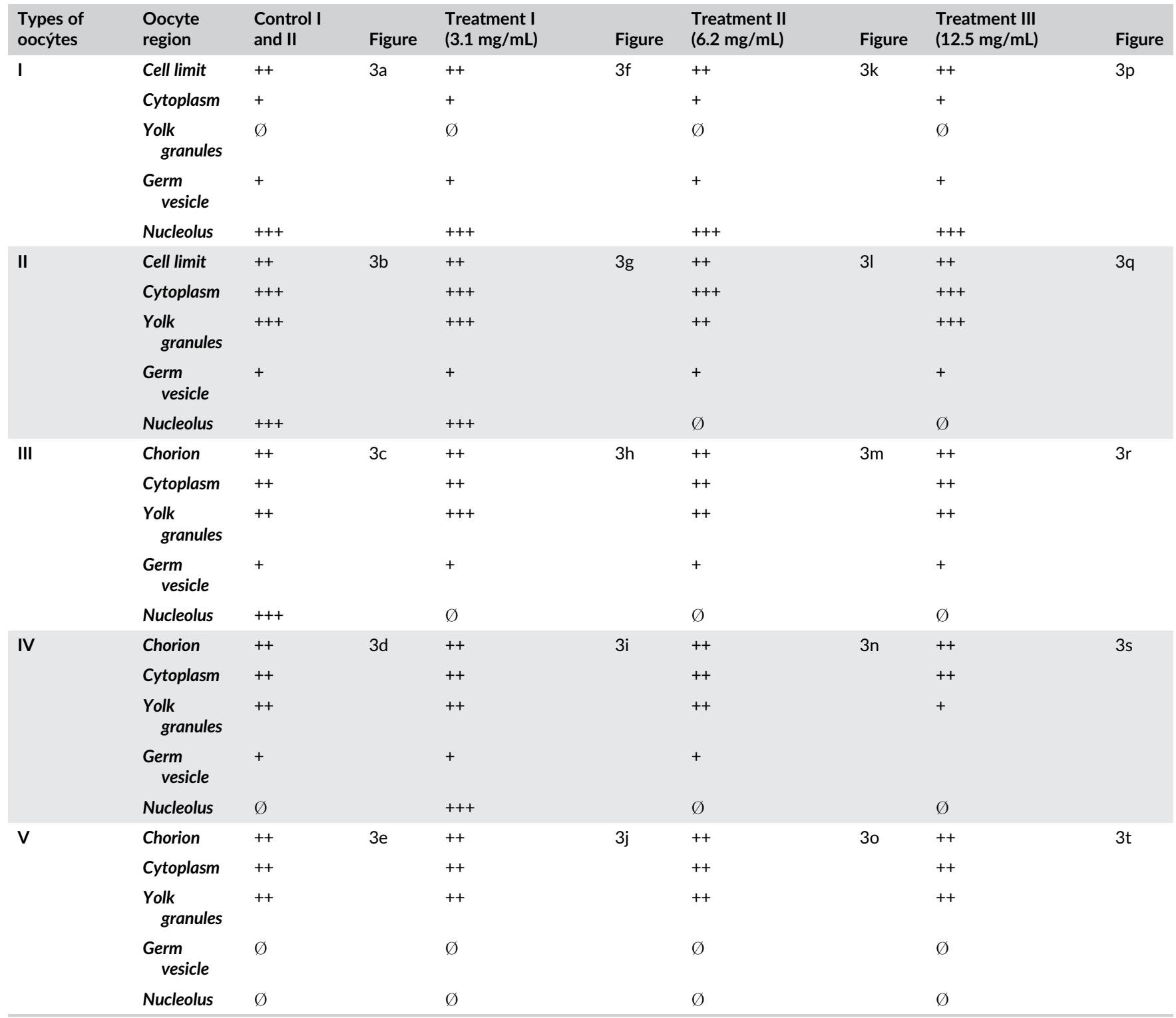

+ weakly positive; ++ moderately positive; +++ strongly positive; - negative; $\varnothing$ region not observed.

positivity (Figure 3c). In the oocytes IV, large and weakly positive yolk granules were found in the central region of the cytoplasm, while small and moderately positive granules were observed in the peripheral region of the cytoplasm (Figure $3 \mathrm{~d}$ ). The germ vesicle, located at the pole facing the oocyte pedicel were weakly positive, and the chorion was moderately positive (Figure $3 d$ ). The oocytes $V$ showed large and weakly positive yolk granules homogeneously distributed in the cytoplasm (Figure 3e). The germ vesicle was not observed and the chorion presented moderate positivity (Figure 3e).

\section{Treatment I: Exposed to $3.1 \mathrm{mg} / \mathrm{mL}$ of EEAO.}

When submitted to bromophenol blue reaction, the semiengorged $A$. cajennense females exposed to $A$. oleracea ethanolic extract at the concentration of $3.1 \mathrm{mg} / \mathrm{mL}$ presented proteins in the oocytes, with significant morphological alterations when compared to the control groups I and II. The oocytes I presented a weakly positive cytoplasm, with vacuoles in the central region of the cytoplasm and around the germ vesicle (Figure $3 f$ ). In oocytes II, the yolk granules were strongly positive to bromophenol blue (Figure $3 g$ ). Differently from the control group, the large yolk grains located mainly in the peripheral region of the oocyte III showed moderate positivity to the reaction, whereas the small granules arranged in the middle portion of the oocyte showed high positivity (Figure $3 \mathrm{~h}$ ). The oocytes IV did not present alterations in comparison with the control group (Figure 3i). In oocytes $\mathrm{V}$, large yolk granules showed moderate to intense positivity to bromophenol blue (Figure 3j).

\section{Treatment II: Exposed to $6.2 \mathrm{mg} / \mathrm{mL}$ of EEAO.}

The histochemical test to detect polysaccharides showed a large number of proteins in the oocytes of the individuals exposed to A. oleracea ethanolic extract at the concentration of $6.2 \mathrm{mg} / \mathrm{mL}$. The cytoplasm of oocytes type I was moderately positive for this technique (Figure 3k). In oocytes II, there was loss of yolk granules, especially in the peripheral region of the cytoplasm, which was weakly positive to the technique (Figure 3l). Differently from the control group, the large yolk grains located mainly in the peripheral region of 


$\begin{array}{cccc}\text { Control } & \text { Treatment I } & \text { Treatment II } & \text { Treatment III } \\ \text { I and II } & 3.1 \mathrm{mg} / \mathrm{mL} & 6.2 \mathrm{mg} / \mathrm{mL} & 12.5 \mathrm{mg} / \mathrm{mL}\end{array}$
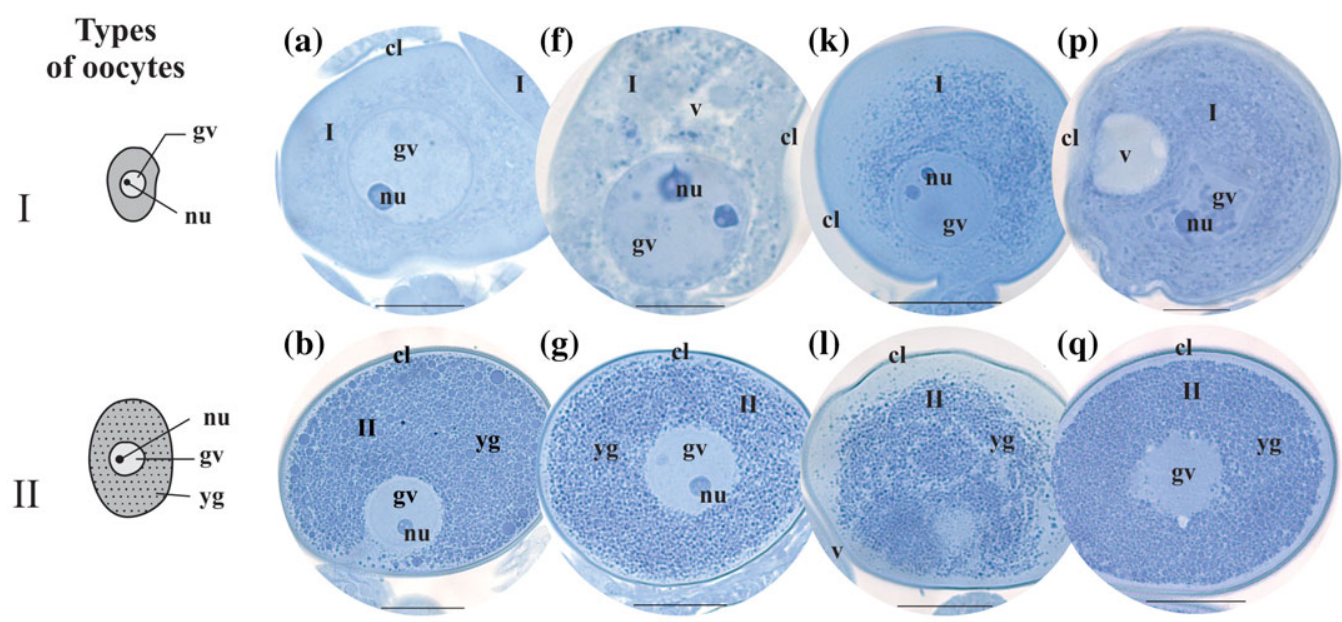

(g)

(l)
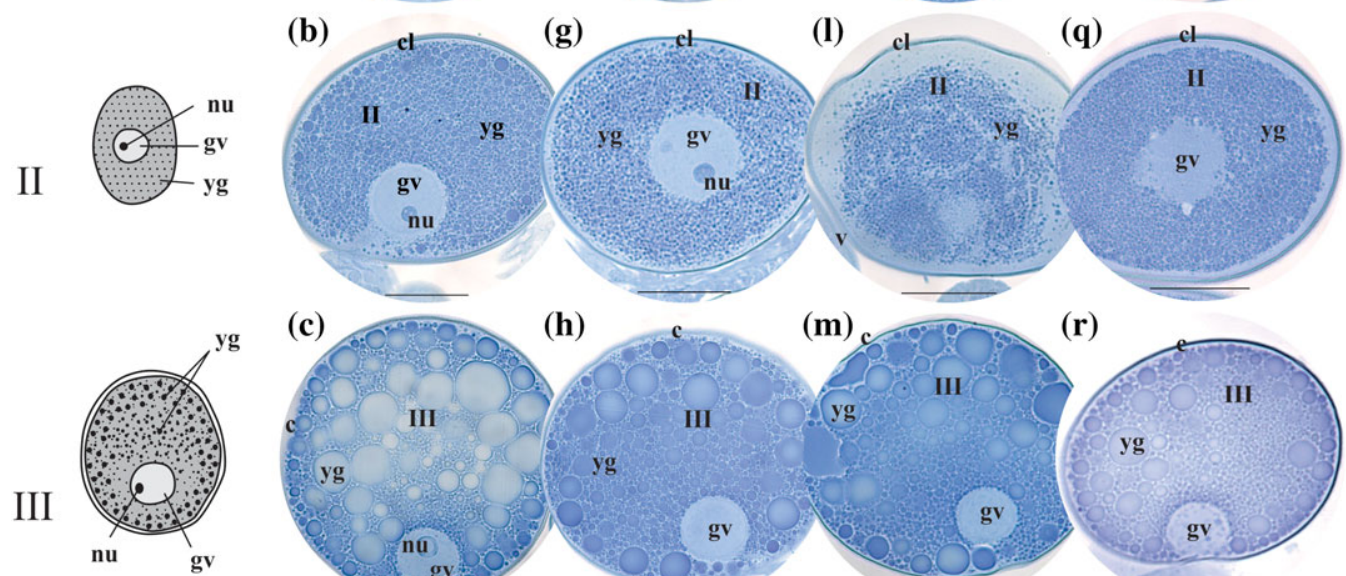

(c)

(h)
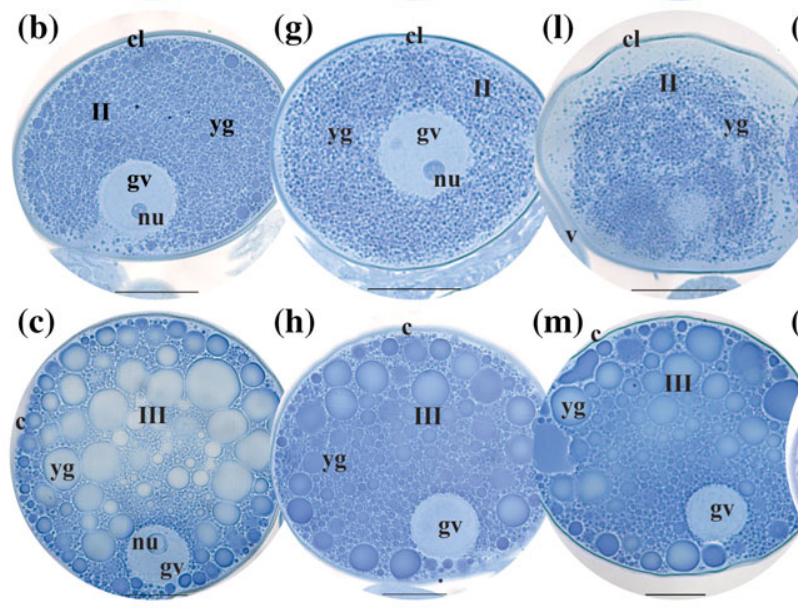

(q)
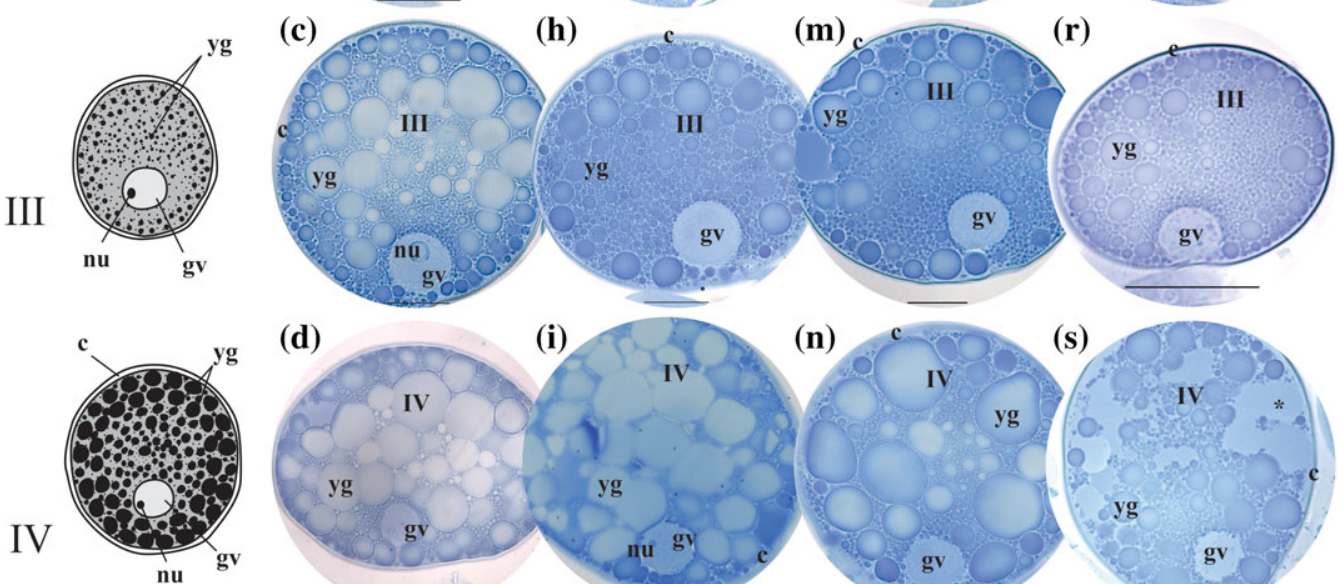

(d)
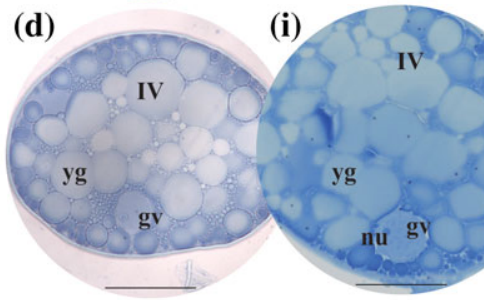

(n)
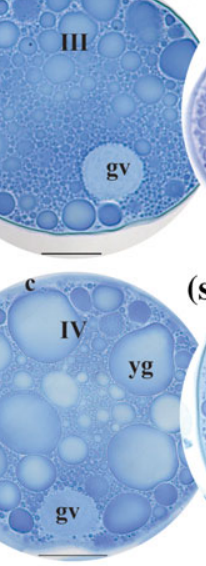

(s)
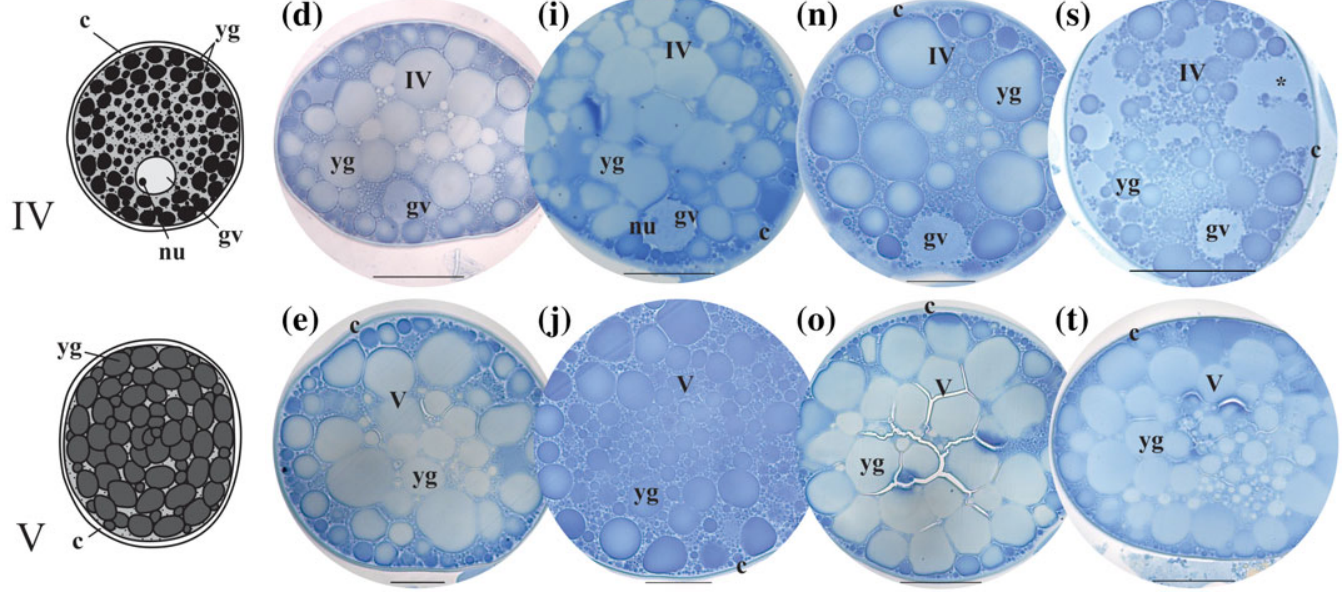

(o)

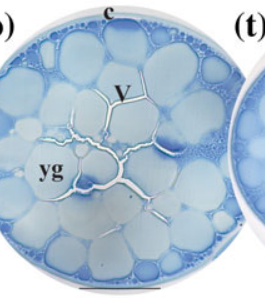

(t)

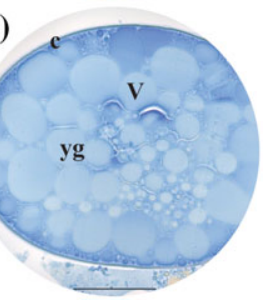

FIGURE 3 Schematic representation of the oocytes (adapted from Oliveira et al. 2005) and histological sections of the ovary from Amblyomma cajennense subjected to bromophenol blue. (a-e) Controls I and II. (f-j) Females exposed to $3.1 \mathrm{mg} / \mathrm{mL}$ do EEAO. (k-o) Females exposed to $6.2 \mathrm{mg} / \mathrm{mL}$ do EEAO. (p-t) Females exposed to $12.5 \mathrm{mg} / \mathrm{mL}$ do EEAO. I = oocyte I; II = oocyte II; III = oocyte III; IV = oocyte IV; V = oocyte V; $\mathrm{c}=$ chorion; $\mathrm{yg}=$ yolk granule; $\mathrm{cl}=$ cell limit; $\mathrm{n}=$ nucleus; $\mathrm{nu}=$ nucleolus; $\mathrm{gv}=$ germ vesicle; $*$ = rupture of the yolk granules. Bars = $\mathrm{a}-\mathrm{d} ; \mathrm{f}-\mathrm{i} ; \mathrm{k}-$ $\mathrm{n} ; \mathrm{p}-\mathrm{s}=50 \mu \mathrm{m} ; \mathrm{e} ; \mathrm{j} ; \mathrm{o} ; \mathrm{t}=100 \mu \mathrm{m}$ [Color figure can be viewed at wileyonlinelibrary.com]

the oocyte III showed moderate positivity to the reaction, whereas the small granules in the middle portion of the oocyte were strongly positive (Figure $3 \mathrm{~m}$ ). The oocytes IV showed moderately positive yolk granules for bromophenol blue (Figure 3n). However, the oocytes $\mathrm{V}$ (Figure 3o) presented no alterations when compared to the control groups.

\section{Treatment III: Exposed to $12.5 \mathrm{mg} / \mathrm{mL}$ of EEAO.}

The female reproductive system of $A$. cajennense exposed to A. oleracea ethanolic extract at the concentration of $12.5 \mathrm{mg} / \mathrm{mL}$ showed proteins in the oocytes when submitted to the bromophenol blue technique. The cytoplasm of the oocytes I presented a large cytoplasmic vacuole, 1yynon-reactive to the technique (Figure 3p). In oocytes II, loss of yolk pellets was observed, mainly in the peripheral region of the oocyte cytoplasm, which was strongly positive for bromophenol blue (Figure 3q). The oocytes III showed the characteristics described in the group treatment III (Figure 3r). In the oocytes IV, there was a fusion of large and weakly positive yolk granules, in addition to the presence of small yolk moderately positive granules (Figure 3s). The oocytes $\mathrm{V}$ did not present any morphological or histochemical alterations (Figure 3t).

\section{4 | DISCUSSION}

Ovaries of Amblyomma cajennense semi-engorged females ticks exposed to three concentrations $(3.1,6.2$, and $12.5 \mathrm{mg} / \mathrm{mL}$ ) of 
A. oleracea ethanolic extract showed morphological and histochemical changes when compared to nontreated organs, mainly in the oocytes in initial developmental stages (I and II). This data corroborates studies by Oliveira et al. (2016) on semi-engorged Rhipicephalus microplus females exposed to the $n$-hexane extract of A. oleracea, Vendramini et al. (2012) on $R$. sanguineus exposed to andiroba oil (Carapa guianensis) and Remedio et al. (2015), who exposed the same species to neem oil (Azadirachta indica). Additionally, an important data obtained in this study was that the cytotoxic potential of the A. oleracea ethanolic extract was very similar to those observed by Oliveira et al. (2008, 2009) and Roma et al. (2010), who tested the synthetic acaricides fipronil and permethrin on $R$. sanguineus, respectively, signalizing the natural chemicals as a potential control strategy. This cytotoxic potential was demonstrated by alterations regarding the morphology of the germinative cells and yolk granules, presence, number, size, and location of vacuoles in the cytoplasm and nuclear alterations in the germinative cells.

In the individuals exposed to A. oleracea ethanolic extract, the oocytes in stages I and III from the treatment group I and those in stages I and II from the treatment groups II and III displayed cytoplasmic disorganization and significant vacuolation (regions that were negative to PAS and Bromophenol blue). Such alterations were also found by Roma et al. (2010) in the oocytes of $R$. sanguineus exposed to the synthetic chemical permethrin. This vacuolation could represent the recycling of cytoplasm portions damaged by the product action, allowing the cell to survive and maintain its viability (Carvalho \& ReccoPimentel, 2012; Junqueira \& Carneiro, 2013). The cytoplasmic vacuoles emerged mainly in oocytes in initial stages of development, corroborating Vendramini et al. (2012) for $R$. sanguineus exposed to andiroba oil and by Oliveira et al. (2016) for R. microplus exposed to nhexane extract from $A$. oleracea. This type of damage could be related to the fact that the chorion is not deposited in oocytes in initial developmental stages, and the chorion functions as a protective barrier that impedes/selects the entry and exit of elements in the cells, including the toxic product (Oliveira et al., 2016). According to Denardi et al. (2004), the chorion deposition would start in oocytes III and be completed in stage V, which means that oocytes I and II are more susceptible.

Still regarding the cytoplasm of the oocytes, alterations and disorganization of the yolk granules were observed in those in stages II to $V$ in the individuals exposed to the concentration of $3.1 \mathrm{mg} / \mathrm{mL}$. In the individuals exposed to the concentration of $6.2 \mathrm{mg} / \mathrm{mL}$, a decrease in the yolk granules may be suggested; and in those exposed to the concentration of $12.5 \mathrm{mg} / \mathrm{mL}$ the granules also may be decreased; however, this alteration was more evident in the peripheral regions of oocytes III. These data are similar to those obtained by Oliveira et al. (2016), who studied the effects of A. oleracea extract on the reproductive system of $R$. microplus and concluded that alterations in the vitellogenesis can lead to a decrease in the yolk granules, and, consequently, to a deficit in the embryo nutrition, affecting the normal development of new individuals.

The oocytes of the individuals exposed to some of the concentrations applied herein showed fragmentation (in addition to vacuolation) of the germ vesicle. Such alteration had already been reported by Denardi et al. (2010), who studied the action of Azadirachta indica on the reproductive system of $R$. sanguineus females, and found that the germ cells start a death process when damaged, interrupting their development and, consequently, the production of new individuals. Therefore, this study confirms that the components of $A$. oleracea extract, even in low concentrations ( 3.1 and $6.2 \mathrm{mg} / \mathrm{mL}$ ), would be able to cause alterations in the germ cells of $A$. cajennense ticks. Studies by Oliveira et al. (2009) on R. sanguineus ticks exposed to fipronil also demonstrated intense and severe morphological alterations in the germ vesicle of the oocytes exposed to the synthetic chemical product.

Moreover, the chorion was supposedly thicker in oocytes $\mathrm{V}$ from the individuals exposed to $3.1 \mathrm{mg} / \mathrm{mL}$ of the $A$. oleracea extract and in oocytes IV and V from the individuals exposed to $6.2 \mathrm{mg} / \mathrm{mL}$. Such thickening would be a strategy of the cells to protect the oocyte content against the damages caused by the toxic substance, corroborating Denardi et al. (2004) and Oliveira et al. (2016).

In ixodid ticks, vitellogenin, the main constituent of the yolk, is synthesized in the fat body, released into the hemolymph and taken up by developing oocytes by endocytosis (Xavier et al., 2018). After this process, it is converted into vitellin, a lipoglycoprotein that will be used during embryogenesis (Xavier et al., 2018).

According to Denardi et al. (2004), the yolk would consist of lipids, proteins, and polysaccharides, deposited in the following order: the lipid is the first one to be synthesized, followed by proteins, and finally by carbohydrates. In this study, for the detection of the presence of polysaccharides and proteins in the ovaries of the semiengorged females from control groups I and II and treatment groups I, II, and III histochemical techniques (PAS and Bromophenol blue, respectively) were used. In the oocytes in stage I of $A$. cajennense, the carbohydrates were not evidenced (weak reactivity to PAS). This fact points that the synthesis and/or incorporation of this element starts in oocytes in stage II, confirming results obtained by Denardi et al. (2004).

According to Ricardo et al. (2007), the production and absorption of carbohydrates would have the participation of pedicel cells and the hemolymph, being therefore exogenous, and would only begin in oocytes II. However, oocytes II of the individuals exposed to A. oleracea extract at concentrations of 6.2 and $12.5 \mathrm{mg} / \mathrm{mL}$ presented a decrease in carbohydrate deposition, when compared to those of the control group. These results are similar to those found by Sampieri et al. (2013), when studying the action of acid esters of castor oil (Ricinus communis) on $R$. sanguineus ticks. The authors suggested that these esters would have action on the hydrolysis of polysaccharides, which would delay the synthesis and incorporation of carbohydrates.

On the other hand, oocytes at stage $V$ from ticks exposed to the concentrations of 6.2 and $12.5 \mathrm{mg} / \mathrm{mL}$ showed high positivity to the PAS reaction when compared to the control group. In ticks, oocytes at stages IV and V of development are at the end of vitellogenesis, which is when the deposition of carbohydrates is performed on a larger scale (Ricardo et al., 2007). Therefore, the high positivity for carbohydrates in oocytes $\mathrm{V}$ of the individuals exposed the concentrations of 6.2 and $12.5 \mathrm{mg} / \mathrm{mL}$ would be related with an increase in the production of these elements. The presence of $A$. oleracea toxic components probably led to a greater lysis of polysaccharide granules, which triggered a higher carbohydrate production (Sampieri et al., 2013). 
Regarding the proteins, the cytoplasm of the oocytes I of the individuals exposed to $A$. oleracea ethanolic extract at the concentrations of 6.2 and $12.5 \mathrm{mg} / \mathrm{mL}$ was moderately positive to Bromophenol blue, whereas those of the control group were weakly positive. According to Oliveira et al. (2005), the synthesis and/or incorporation of proteins by early-stage oocytes is slow. Therefore, the extract would be stimulating the protein synthesis in oocytes I, which would be using the proteins to produce enzymes to neutralize the toxic action of the extract in an attempt to maintain the integrity and viability of the cell rather than performing the yolk composition (Roma, Furquim, Bechara, \& Camargo-Mathias, 2011). Similar data were found by Roma et al. (2010), who studied the cytotoxic effects of permethrin on $R$. sanguineus oocytes.

Moreover, the extract caused a gradual reduction in the number of protein elements, especially in the oocytes II, III, and IV in the treatment groups I, II, and III. These modifications occurred due to the vacuolation in the interior of the cells, the decrease in the number and size of yolk granules and the decrease in affinity to the histochemical stain (in the cytoplasm, yolk granules, and membranes).

Such data indicate that the treatment with $A$. oleracea extract affected the synthesis and storage of polysaccharides and proteins in the germinative cells of the $R$. sanguineus females treated. Consequently, several components of the germinative cells would become fragile, deformed and the synthesis and storage of yolk would be compromised (quantitatively and qualitatively). As a result, the forming germinative cells would be so impaired that they would not be capable to originate a new individual.

In conclusion, the data obtained in this study confirmed the cytotoxic potential of $A$. oleracea ethanolic extract at the concentrations of 3.1, 6.2, and $12.5 \mathrm{mg} / \mathrm{mL}$ on the germ cells of A. cajennense female ticks, opening up the possibility to use this chemical as an efficient alternative to control these ectoparasites.

\section{ACKNOWLEDGMENTS}

The authors would like to thank São Paulo Research Foundation (FAPESP) Grant no. 2015/01496-5 and CAPES/Brazil for the financial support.

\section{ORCID}

Luís Adriano Anholeto (D) http://orcid.org/0000-0001-8712-2630

Patrícia Rosa de Oliveira (D) http://orcid.org/0000-0002-2695-2101

Rodney Alexandre Ferreira Rodrigues (D) http://orcid.org/0000-00015631-0970

Maria Izabel Camargo-Mathias (D) http://orcid.org/0000-0002-

9418-8934

\section{REFERENCES}

Agnolin, C. A., Olivo, C. J., Leal, M. L. R., Beck, R. C. R., Meinerz, G. R., Parra, C. L. C., ... Nicolodi, P. R. S. (2010). Eficácia do óleo de citronela [Cymbopogon nardus (L.) Rendle] no controle de ectoparasitas de bovinos. Revista Brasileira de Plantas Medicinais, 12(4), 482-487. https:// doi.org/10.1590/S1516-05722010000400012

Anholeto, L. A., Oliveira, P. R., Rodrigues, R. A. F., Spindola, C. D. S. Labruna, M. B., Pizano, M. A., ... Camargo-Mathias, M. I. (2017)
Potential action of extract of Acmella oleracea (L.) R.K. Jansen to control Amblyomma cajennense (Fabricius, 1787) (Acari: Ixodidae) ticks. Ticks and Tick-Borne Diseases, 8(1), 65-72. https://doi.org/10.1016/j. ttbdis.2016.09.018

Barbosa, A. F., Carvalho, M. G., Smith, R. E., \& Sabaa-Srur, A. U. O. (2016). Spilanthol: Occurrence, extraction, chemistry and biological activities. Revista Brasileira de Farmacognosia, 26(1), 128-133. https://doi.org/10. 1016/j.bjp.2015.07.024

Beati, L., Nava, S., Burkman, E. J., Barros-Battesti, D. M., Labruna, M. B., Guglielmone, A. A., ... Faccini, J. L. H. (2013). Amblyomma cajennense (Fabricius, 1787) (Acari: Ixodidae), the Cayenne tick: Phylogeography and evidence for allopatric speciation. BMC Evolutionary Biology, 13(1), 267. https://doi.org/10.1186/1471-2148-13-267

Borges, L. M. F., Sousa, L. A. D., \& Barbosa, C. S. (2011). Perspectives for the use of plant extracts to control the cattle tick Rhipicephalus (Boophilus) microplus. Brazilian Journal of Veterinary Parasitology, 20(2), 89-96.

Carvalho, H. F., \& Recco-Pimentel, S. M. (2012). A Célula (3). São Paulo: Editora Manole.

Castro, K. N. C., Lima, D. F., Vasconcelos, L. C., Leite, J. R. S. A., Santos, R. C., Paz Neto, A. A., \& Costa-Júnior, L. M. (2014). Acaricide activity in vitro of Acmella oleracea against Rhipicephalus microplus. Parasitology Research, 113(10), 3697-3701. https://doi.org/10.1007/ s00436-014-4034-2

Cheng, Y.-B., Liu, R., Ho, M.-C., Wu, T.-Y., Chen, C.-Y., Lo, I.-W., ... Chang, F.-R. (2015). Alkylamides of Acmella oleracea. Molecules, 20(4), 6970-6977. https://doi.org/10.3390/molecules20046970

Denardi, S. E., Bechara, G. H., Oliveira, P. R., \& Camargo-Mathias, M. I. (2010). Azadirachta indica a. Juss (neem) induced morphological changes on oocytes of Rhipicephalus sanguineus (Latreille, 1806) (Acari: Ixodidae) tick females. Experimental Parasitology, 126(4), 462-470. https://doi.org/10.1016/j.exppara.2010.05.017

Denardi, S. E., Bechara, G. H., Oliveira, P. R. !de, Nunes, E. T., Saito, K. C., \& Camargo-Mathias, M. I. (2004). Morphological characterization of the ovary and vitellogenesis dynamics in the tick Amblyomma cajennense (Acari: Ixodidae). Veterinary Parasitology, 125(3-4), 379-395. https:// doi.org/10.1016/j.vetpar.2004.07.015

Drummond, R. O., Ernst, S. E., Trevino, J. L., Gladney, W. J., \& Graham, O. H. (1973). Boophilus annulatus and B. microplus: Laboratory tests of insecticides. Journal of Economic Entomology, 66(1), 130-133.

Dubey, S., Maity, S., Singh, M., Saraf, S. A., \& Saha, S. (2013). Phytochemistry, pharmacology and toxicology of Spilanthes acmella: A review. Advances in Pharmacological Sciences, 2013(423750), 1-9. https://doi. org/10.1155/2013/423750

Estrada-Peña, A., \& De La Fuente, J. (2014). The ecology of ticks and epidemiology of tick-borne viral diseases. Antiviral Research, 108, 104-128. https://doi.org/10.1016/j.antiviral.2014.05.016

Fabry, W., Okemo, P., \& Ansorg, R. (1996). Fungistatic and fungicidal activity of east African medicinal plants. Mycoses, 39(1-2), 67-70.

Favoreto, R., \& Gilbert, B. (2010). Estado da Arte/state of the art - Acmella oleracea (L.) R. K. Jansen (Asteraceae) - Jambu. Revista Fitos, 5(1), 83-91.

Junqueira, L. C., \& Carneiro, J. (2013). Histologia Básica. Rio de Janeiro: Guanabara Koogan.

Junqueira, L. C. U., \& Junqueira, L. M. M. S. (1983). Técnicas básicas de citologia e histologia. São Paulo: Livraria Editora Santos.

Labruna, M. B. (2009). Ecology of rickettsia in South America. Annals of the New York Academy of Sciences, 1166, 156-166. https://doi.org/10. 1111/j.1749-6632.2009.04516.x

Martinez, S. S. (2002). In S. S. Martinez (Ed.), O Nim - Azadirachta indica: Natureza, usos múltiplos. Londrina: IAPAR.

Martins, T. F., Barbieri, A. R. M., Costa, F. B., Terassini, F. A., Camargo, L. M. A., Peterka, C. R. L., ... Labruna, M. B. (2016). Geographical distribution of Amblyomma cajennense (sensu lato) ticks (Parasitiformes: Ixodidae) in Brazil, with description of the nymph of A. cajennense (sensu stricto). Parasites \& Vectors, 9(1), 186. https://doi. org/10.1186/s13071-016-1460-2

Nigrinis, L. S. O. de, Caro, J. O., \& Olarte, E. N. (1986). Estudio fitofarmacológico de la fraccion liposoluble de las flores de la Spilanthes americana (Mutis) parte I: Estudio fitoquimico. Revista Colombiana de Ciências Químico-Farmacêuticas, 15, 37-47. 
Nolan, J. (1985). Mechanisms of resistance to chemicals in arthropod parasites of veterinary importance. Veterinary Parasitology, 18(2), 155-166. https://doi.org/10.1016/0304-4017(85)90064-0

Nomura, E. C. O., Rodrigues, M. R. A., Silva, C. F., Hamm, L. A., Nascimento, A. M., Souza, L. M., ... de Werner, M. F. P. (2013). Antinociceptive effects of ethanolic extract from the flowers of Acmella oleracea (L.) R.K. Jansen in mice. Journal of Ethnopharmacology, 150(2), 583-589. https://doi.org/10.1016/j.jep.2013.09.007

Oelrichs, P. B., Hill, M. W., Vallely, P. J., MacLeod, J. K., \& Molinski, T. F. (1983). Toxic tetranortriterpenes of the fruit of Melia azedarach. Phytochemistry, 22(2), 531-534. https://doi.org/10.1016/0031-9422(83)83039-8

Oliveira, P. R., Bechara, G. H., Marin-Morales, M. A., \& Camargo-Mathias, M. I. (2009). Action of the chemical agent fipronil on the reproductive process of semi-engorged females of the tick Rhipicephalus sanguineus (Latreille, 1806) (Acari: Ixodidae). Ultrastructural evaluation of ovary cells. Food and Chemical Toxicology, 47(6), 1255-1264. https://doi.org/10.1016/j.fct.2009.02.019

Oliveira, P. R., Pizano, M. A., Remédio, R. N., Bechara, G. H. Abreu, R. M. M., ... Camargo-Mathias, M. I. (2015). Potential of the chemical dinotefuran in the control of Rhipicephalus sanguineus (Latreille, 1806) (Acari: Ixodidae) semi-engorged female ticks. Experimental Parasitology, 155, 82-88. https://doi.org/10.1016/j.exppara. 2015.04.021

Oliveira, P. R., Bechara, G. H., \& Camargo-Mathias, M. I. (2008). Evaluation of cytotoxic effects of fipronil on ovaries of semi-engorged Rhipicephalus sanguineus (Latreille, 1806) (Acari: Ixodidae) tick female. Food and Chemical Toxicology, 46(7), 2459-2465. https://doi.org/10.1016/j.fct. 2008.03.034

Oliveira, P. R., Bechara, G. H., Denardi, S. E., Nunes, E. T., \& Camargo-Mathias, M. I. (2005). Morphological characterization of the ovary and oocytes vitellogenesis of the tick Rhipicephalus sanguineus (Latreille, 1806) (Acari: Ixodidae). Experimental Parasitology, 110(2), 146-156. https://doi.org/10.1016/j.exppara.2004.12.016

Oliveira, P. R., Bechara, G. H., Denardi, S. E., Pizano, M. A., \& Camargo-Mathias, M. I. (2011). Toxicity effect of the acaricide fipronil in semi-engorged females of the tick Rhipicephalus sanguineus (Latreille, 1806) (Acari: Ixodidae): Preliminary determination of the minimum lethal concentration and LC(50). Experimental Parasitology, 127(2), 418-422. https://doi.org/10.1016/j.exppara.2010.09.009

Oliveira, P. R., Castro, K. N. d. C., Anholeto, L. A., \& Camargo Mathias, M. I. (2016). Cytotoxic effects of extract of Acmella oleracea (Jambú) in Rhipicephalus microplus females ticks. Microscopy Research and Technique, 79(8), 744-753. https://doi.org/10.1002/jemt.22693

Pearse, A. (1985). Histochemistry theoretical and applied. Churchill: Livingstone.

Pruett, J. H. (1999). Immunological control of arthropod ectoparasites - a review. International Journal for Parasitology, 29(1), 25-32. https://doi. org/10.1016/S0020-7519(98)00172-6

Ramsewak, R. (1999). Bioactive $\mathrm{N}$-isobutylamides from the flower buds of Spilanthes acmella. Phytochemistry, 51(6), 729-732. https://doi.org/10. 1016/S0031-9422(99)00101-6

Remedio, R. N., Nunes, P. H., Anholeto, L. A., Oliveira, P. R., \& Camargo-Mathias, M. I. (2015). Morphological effects of neem (Azadirachta indica a. Juss) seed oil with known azadirachtin concentrations on the oocytes of semi-engorged Rhipicephalus sanguineus ticks (Acari: Ixodidae). Parasitology Research, 114(2), 431-444. https://doi.org/10. 1007/s00436-014-4200-6

Ricardo, A. J., Oliveira, P. R., Bechara, G. H., \& Camargo-Mathias, M. I. (2007). Ultrastructural detection of proteins, lipids and carbohydrates in oocytes of Amblyomma triste (Koch, 1844) (Acari; Ixodidae) during the vitellogenesis process. Tissue and Cell, 39(3), 203-215. https://doi. org/10.1016/J.TICE.2007.03.005

Roma, G. C., Furquim, K. C. S., Bechara, G. H., \& Camargo-Mathias, M. I. (2010). Permethrin-induced morphological changes in oocytes of Rhipicephalus sanguineus (Acari: Ixodidae) semi-engorged females. Food and Chemical Toxicology, 48(3), 825-830. https://doi.org/10.1016/j.fct. 2009.12.016

Roma, G. C., Furquim, K. C. S., Bechara, G. H., \& Camargo-Mathias, M. I. (2011). Cytotoxic effects of permethrin in oocytes of Rhipicephalus sanguineus (Acari: Ixodidae) fully engorged females: I. direct or indirect action of the acaricide in germ cells? Experimental and Applied Acarology, 53(3), 287-299. https://doi.org/10.1007/s10493-010-9401-9

Saito, K. C., Bechara, G. H., Nunes, E. T., Oliveira, P. R., Denardi, S. E., \& Camargo-Mathias, M. I. (2005). Morphological, histological, and ultrastructural studies of the ovary of the cattle-tick Boophilus microplus (Canestrini, 1887) (Acari: Ixodidae). Veterinary Parasitology, 129(3-4), 299-311. https://doi.org/10.1016/j.vetpar.2004.09.020

Sampieri, B. R., Arnosti, A., Furquim, K. C. S., Chierice, G. O. Bechara, G. H., Carvalho, P. L. P. F., ... Camargo-Mathias, M. I. (2013). Effect of ricinoleic acid esters from castor oil (Ricinus communis) on the oocyte yolk components of the tick Rhipicephalus sanguineus (Latreille, 1806) (Acari: Ixodidae). Veterinary Parasitology, 191(3-4), 315-322. https://doi.org/10.1016/j.vetpar.2012.09.013

Soares, H. S., Barbieri, A. R. M., Martins, T. F., Minervino, A. H. H., Lima, J. T. R., Marcili, A., ... Labruna, M. B. (2015). Ticks and rickettsial infection in the wildlife of two regions of the Brazilian Amazon. Experimental \& Applied Acarology, 65(1), 125-140. https://doi.org/10.1007/ s10493-014-9851-6

Sonenshine, D. E., \& Roe, R. M. (2014). Biology of ticks. (D. E. Sonenshine \& R. M. Roe, Eds.) (2 $\left.{ }^{\mathrm{a}}\right)$. New York: Oxford University Press.

Tarragona, E. L., Cicuttin, G. L., Mangold, A. J., Mastropaolo, M., Nazarena De Salvo, M., \& Nava, S. (2015). Rickettsia infection in Amblyomma tonelliae, a tick species from the Amblyomma cajennense complex. Ticks and Tick-Borne Diseases, 6(2), 173-177. https://doi.org/10.1016/j. ttbdis.2014.11.010

Torres, J. M., \& Chávez, A. G. (2001). Alcamidas en plantas: distribución e importancia. Avance y Perspectiva, 20(Noviembre-Diciembre), 377-387.

Vendramini, M. C. R., Camargo-Mathias, M. I., Faria, A. U., Bechara, G. H. Oliveira, P. R., \& Roma, G. C. (2012). Cytotoxic effects of andiroba oil (Carapa guianensis) in reproductive system of Rhipicephalus sanguineus (Latreille, 1806) (Acari: Ixodidae) semi-engorged females. Parasitology Research, 111(5), 1885-1894. https://doi.org/10.1007/ s00436-012-3031-6

Xavier, M. A., Tirloni, L., Pinto, A. F. M., Diedrich, J. K., Yates, J. R., Mulenga, A., ... Termignoni, C. (2018). A proteomic insight into vitellogenesis during tick ovary maturation. Scientific Reports, 8(1), 4698. https://doi.org/10.1038/s41598-018-23090-2

How to cite this article: Anholeto LA, de Oliveira PR, Rodrigues RAF, Yamane LT, Castro Karina Neoob de Carvalho, Camargo-Mathias MI. Morphological alterations in the ovaries of Amblyomma cajennense semi-engorged ticks exposed to ethanolic extract of Acmella oleracea. Microsc Res Tech. 2018; 1-11. https://doi.org/10.1002/jemt.23145 